The patient was a Hausa woman, aged 50, cause of the deficiency was discovered, but living in a village in the savanna zone near Mallumfashi, North Central State, Nigeria. She complained of fever and dizziness for six weeks, weakness so that she was unable to walk more than about half a mile $(805 \mathrm{~m})$, and swelling of the feet for one week. She admitted to two pregnancies, with both children alive, the younger being about 12 years old. She gave no history of any previous illness. She appeared well nourished (weight $37.5 \mathrm{~kg}$ ) but severely anaemic, with oedema of the feet and hyperpigmentation of both palms and soles (Fig. 1). Her haemoglobin

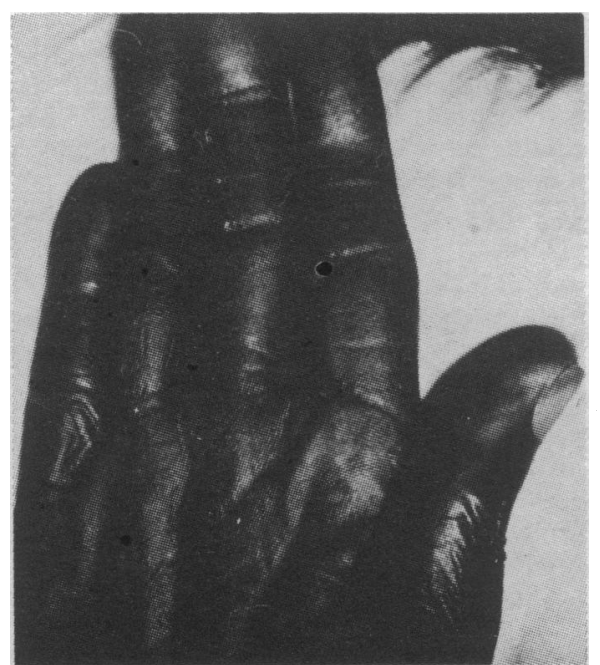

(Hb) concentration was $4.5 \mathrm{~g} / 100 \mathrm{ml}$, with anisocytosis, both macrocytosis and microcytosis; polychromasia; hypochromia; and nucleated red cells in the peripheral blood smear. Bone marrow smears showed megaloblastic erythropoiesis, giant metamyelocytes, and stainable intracellular iron plentiful in the reticuloendothelial cells but not in the erythroid precursors. The total white cell count was $6,900 / \mu 1$, with a normal differential count but hypersegmentation of neutrophil polymorphs; Hb electrophoretic pattern was AA, the serum vitamin $B_{12}$ concentration was $1,000 \mathrm{pg} /$ ml (Professor B. O. Osuntokun, University of Ibadan), but the serum and red-cell folate activities were not estimated as the patient had received oral folic acid before specimens could be collected. A histamine test meal showed no free acid and the total acid was $3.0 \mathrm{mEq} / 1$. Skin tissue for biopsy was not taken until the eleventh day after admission, when the patient was showing a haematological remission following folic acid therapy. The skin colour had not faded by this time and the section showed hyperkeratotic squamous epithelium with numerous pigment-containing melanophores in the basal layer. There was no other histological difference from normal pigmented skin.

The patient received oral folic acid $5 \mathrm{mg} /$ day for two days before the possibility of vitamin $B_{12}$ deficiency was considered and this therapy stopped. She had a reticulocyte response reaching a maximum of $15 \%$ on the fifth day; the $\mathrm{Hb}$ began to rise from the eighth day to reach $10.5 \mathrm{~g} / 100 \mathrm{ml}$ on day 21 and $11.5 \mathrm{~g} / 100 \mathrm{ml}$ on day 27. Cyanocobalamin $1 \mu \mathrm{g} /$ day was given intramuscularly from day 21 to 29 , but there was no further reticulocyte response. She received ferrous sulphate $200 \mathrm{mg}$ three times a day for 29 days; she took the normal ward diet. She was discharged from hospital on day 29 with a supply of oral folic acid but was not seen again. The pigmentation had faded and her palms and soles were normal.

Investigations were far from complete in this patient, but vitamin $\mathbf{B}_{12}$ deficiency was excluded by bioassay and she showed a complete haematological remission after oral folic acid. It may be concluded that her megalo blastic anaemia and skin hyperpigmentation were both the result of folate deficiency. No the presence of hypochromic microcytes and intracellular iron in the histiocytes but not in the red cell precursors suggested that there was an underlying chronic inflammatory process.

Vitamin $\mathbf{B}_{12}$ deficiency is usually more long-standing than folate deficiency at the time of diagnosis. It may be that skin pigmentation is a reflection of chronicity of megaloblastosis rather than specific to vitamin $\mathbf{B}_{12}$ deficiency, and this would explain why folate-deficient South African show the sign in the late postnatal period while Nigerians do not when they are rapidly depleted by the demands of malarial haemolysis and pregnancy. The present patient was likely to have had a longstanding deficiency. Patients with sickle cell anaemia are sometimes deficient in folate for long periods before diagnosis, and it will be interesting to hear whether this sign has been noticed in these individuals.

The mechanism of hyperpigmentation remains obscure. Attempts to demonstrate a disturbance of melanin synthesis have not been helpful.5-7 Alternatively, it could be manifestation of altered cell division, which had reverted to normal by the time the skin was examined histologically in the present subject.

We thank Professor E. H. O. Parry and Dr N. McD. Davidson for permission to publish details of this patient, who was under their care. We are, etc.

Department of Pathology,

A. F. Fleming

Zaria, Nigeria

Westminster Medical School,

Udall Street Laboratories,

1 Baker, S. J., Ignatius, M., Johnson, S., and Vaish, S. K.', British Medical fourmal, 1963, 1, 1713. Blood, 1966, 28, 770.

Baumslag, N., and Metz, J., British Medical fournal, 1969, 2, 737

Fleming, A. F., and Ive, F. A., British Medical

Fournal, 1969, 3, 238.
Fleming. A. F., and Broquist, H. P., American Sournal of Clinical Nutrition, 1967, 20, 613. S J., Clinica Chimica Acta, 1968, 20, 53 . Baker,'s. J., Mathan, V. I., and Abe, K., Blood,
1970, 35, 83.

\section{Dissecting Aneurysm and Autoimmune} Thyroiditis

SIR,-Hashimoto's disease is reported with lymphomas $^{1}$ and thymomas, ${ }^{2}$ and also after sarcoid thyroiditis. ${ }^{3}$ In this syndrome the chronic irritation of prolonged cellular immunity sometimes seems to alter and accelerate cell division so that neoplasms develop. The Hashimoto's thyroiditis in the 75-year-old woman with hypertension, reported by Drs. Angela Hilton and R. S. Whittaker (30 September, p. 827), was perhaps related more closely to the earlier bladder carcinoma than to the degenerative dissecting aneurysm.-I am, etc.,

\section{Chilworth, Surrey}

\section{G. A. MacGregor}

1 Cox, M. T., Fournal of Clinical Pathology, 1964 Dawson, M. A., American Fournal of Medicine, Karlish, A. J., and MacGregor, G. A., Lancet, $1970,2,330$.

MacGregor, G. A., British Medical fournal, 1972
Ahmadu Bello University,
Foley-catheter Induction of Labour

SIR,-During the discussion time of a recent Upjohn symposium on prostaglandins I mentioned a method of inducing labour with the help of a Foley catheter. Since then I have had a number of inquiries about the technique. It was introduced to the Bedford maternity department in 1967 after I had read a paper by Embrey and Mollison, 1 and it is used for induction of labour only when the cervix is found to be unripe and unfavourable. Like the original authors, I have found it to be effective and sepsis has not been a problem.

The patient is given Pamergan P100 (pethidine hydrochloride $100 \mathrm{mg}$ and promethazine hydrochloride $50 \mathrm{mg}$ ) as premedication. She is then asked to pass urine and catheterization is avoided if possible. After placing her in the lithotomy position and carrying out the usual aseptic preparation the pelvis and cervix are assessed. If the cervix is found to be ripe and the presenting part favourable a low amniotomy is performed using Smyth's torceps or Dumoulin's instrument. If the cervix is unripe a 26-gauge Foley catheter is used. The tip beyond the balloon is cut off with sterile scissors before insertion. The catheter is then passed so that the balloon lies just inside the internal os and $50 \mathrm{ml}$ of sterile water is inserted. Occasionally the os is so tightly closed that it is necessary to expose the cervix with a speculum and to hold its anterior lip with a pair of sponge-holding forceps.

If the catheter has not been passed spontaneously after 12 to 24 hours it is removed and the cervix reassessed. Almost always the cervix is found to have become effaced and partially dilated. A low amniotomy is then performed and usually labour progresses soon afterwards. Occasionally further stimulation of the uterus is required with intravenous oxytocin. Prophylactic antibiotics are not given.-I am, etc.,

Bedford General Hospital

J. R. SAUNDERS

1 Embrey, M. P., and Mollison, B. G., fournal of Obstetrics and Gynaecology British Common-
wealth, 1967, 74, 44.

\section{General Practice Observed}

SIR,-Your leading article, "General Practice Observed" (30 September, p. 781), drew attention to the recent flood of reports on general practice. After reading these documents it is perhaps worth making one or two points before we all get overwhelmed by a plethora of verbal nonsense.

Firstly. it is now being stated as if it were a brand-new discovery that general practitioners need to understand human behaviour and learn about the patients' social and cultural background and their influence on disease. Secondly, the move accelerates to involve general practitioners in hospital work, including the revival of that once oft-maligned institution the G.P. hospital.

While most of us accept the need to try to improve general practice, especially with the advent of the new larger impersonal health centres, and the increasing use of deputizing services, these two points are but a return to the old pattern of general practice obtaining 50 or more years ago and carried on successfully by family doctors who had little if any formalized vocational training. All of which makes one question whether too much emphasis is being placed on vocational training sohemes, many in 